\title{
Relationship between HTLV-III Neutralizing Antibody and Clinical Status of Pediatric Acquired Immunodeficiency Syndrome (AIDS) and AIDS-Related Complex Cases
}

\author{
MARJORIE ROBERT-GUROFF, JAMES M. OLESKE, EDWARD M. CONNOR, LEON G. EPSTEIN, \\ ANTHONY B. MINNEFOR, AND ROBERT C. GALLO \\ Laboratory of Tumor Cell Biology, National Cancer Institute, National Institutes of Health, Bethesda, Maryland \\ 20892 [M.R.-G., R.C.G.]; Department of Pediatrics, Division of Allergy, Immunology and Infectious Diseases, \\ University of Medicine and Dentistry of New Jersey, New Jersey Medical School, Newark, New Jersey 07103 \\ [J.M.O., E.M.C., L.G.E.]; St. Joseph's Hospital and Medical Center, Paterson, New Jersey 07503 [A.B.M.]
}

\begin{abstract}
To investigate a possible protective role of HTLV-III neutralizing antibodies in individuals exposed to the virus, sera of children with acquired immunodeficiency syndrome or acquired immunodeficiency syndromerelated complex were analyzed for neutralizability of HTLV-IIIB infectivity. Twelve pediatric patients (nine acquired immunodeficiency syndrome, three acquired immunodeficiency syndrome-related complex) were clinically stable and had survived more than 2 yr postonset. Their predominant clinical problems included lymphocytic interstitial pneumonia, candidiasis, recurrent bacterial infections, failure to thrive, and lymphadenopathy. Twelve additional children (all acquired immunodeficiency syndrome) were classified as clinically poor; 10 of them had died. Their median length of survival was less then $2 \mathrm{yr}$, and their disease spectrum included progressive encephalopathy, thymic depletion or atrophy, and Pneumocystis carinii pneumonia in addition to many of the clinical features of the stable children. All $(100 \%)$ of the stable patients possessed serum neutralizing antibody in contrast to only one of the $12(8 \%)$ clinically poor patients. A simple decline in immunologic reactivity to HTLV-III antigens with disease progression did not account for this difference, since HTLV-III antibody titers of the clinically poor cases $(1 \times$ $10^{2}$ to $1 \times 10^{7}$ ) ranged as high as those of the stable cases $\left(1 \times 10^{4}\right.$ to $\left.1 \times 10^{7}\right)$ when measured by the ELISA technique. Although stable cases possessed a higher geometric mean titer $\left(2.8 \times 10^{5}\right)$ by ELISA than the poor cases $\left(4 \times 10^{4}\right)$, this difference was not statistically significant. Serial serum samples from stable children exhibited continual neutralizing antibody activity while two of three clinically poor cases lacked neutralizing activity in serial specimens. The neutralizing antibody status of mothers of both groups was similar and unrelated to the clinical course of their children's disease. These data suggest that in pediatric patients, HTLV-III neutralizing antibodies may have a protective effect. Whether these antibodies also influence the spectrum of disease manifested and whether neutralizing antibody has prognostic value must be established by future studies. (Pediatr Res 21: 547-550, 1987)
\end{abstract}

Received July 16, 1986; January 2, 1987.

Address correspondence and reprint requests to Marjorie Robert-Guroff, Ph.D., National Institutes of Health, National Cancer Institute, Building 37, Room 6A09, Bethesda, MD 20892

\section{Abbreviations}

AIDS, acquired immunodeficiency syndrome ARC, AIDS-related complex

LIP, lymphoid interstitial pneumonitis

IV, intravenous

The discovery that the etiologic agent of AIDS, HTLV-III (1) also termed LAV (2) and recently HIV (3), could elicit natural antibodies capable of neutralizing the infectivity of the virus (4 5) has influenced subsequent AIDS research. Of practical importance is the fact the systems described can be utilized to analyze various vaccine preparations for their efficacy in eliciting neutralizing antibodies in animal models. Moreover, the same systems make feasible the mapping of viral envelope regions in order to elucidate those important for infectivity and neutralization. These investigations will provide new targets for potential vaccine preparation. However, the question of whether neutralizing antibodies have biologic significance in the infected individual has not been answered. Initial studies in adults correlated higher neutralizing antibody titers with less severe disease manifestation suggesting that neutralizing antibodies might have some protective effect in vivo (5). However, the fact that the antibody titers observed in general were low indicated that this reactivity might play a minor role in immune surveillance against the viral agent. In order to pursue this question we investigated sera of children with AIDS and ARC for neutralizing antibody activity. The choice of sera of pediatric patients allowed for fewer variables in disease progression, as the children in general were not subject to repeated external exposures from variable viral sources.

\section{METHODS}

Sera. Sera analyzed represented children with AIDS or ARC who had been classified as clinically stable or clinically poor. All children studied were sero-positive for HTLV-III/LAV and exhibited immunologic abnormalities. A diagnosis of AIDS was made according to the case definition of the Centers for Disease Control (6) and included patients with LIP (7). Children with ARC had similar clinical and immunologic features as those with AIDS but lacked opportunistic infections, Kaposi's sarcoma, and LIP. Children were characterized as clinically stable if they did 
not require aggressive therapies and had been maintained as outpatients for more than 6 months. Clinically poor children in contrast did require aggressive therapy and frequent hospitalization. The clinical features of the children studied are summarized in Table 1 . Of all the 24 patients, 23 had been treated with intravenous $\gamma$ globulin. Twenty-two of the children had acquired the disease congenitally or in early infancy. Mothers of the children were the primary source of HTLV-III infection. Of 12 children classified as clinically stable, nine had IV drug-abusing mothers, one had a mother with AIDS, and two had an IV drugabusing father. Of 12 children categorized as clinically poor, six had IV-drug abusing mothers, one had an IV drug-abusing father, two had received blood transfusions in infancy, one was an infant born to a recent Haitian emigrant, and two were hemophiliacs. Age at infection of the latter two children could not be determined. All sera were obtained coded and antibody analyses were carried out without knowledge of patient identity or disease status. The sera studied were collected from 1982 to 1985 and were maintained at $-70^{\circ} \mathrm{C}$ until assay.

Antibody analysis. HTLV-III neutralizing antibody activity was assayed as previously described (5). Briefly, 20- $\mu$ l aliquots of a 1:100 dilution of direct pelleted HTLV-IIIB from a liter of clarified tissue culture media containing 2 to $5 \times 10^{8}$ particles/ $\mathrm{ml}$ were incubated with $20-\mu \mathrm{l}$ aliquots of $1: 10$ dilutions of heat inactivated, filter sterilized sera for $1 \mathrm{~h}$ at $4^{\circ} \mathrm{C}$ and $15 \mathrm{~min}$ at room temperature. Ten- $\mu$ l aliquots of polybrene treated permissive $\mathrm{H} 9$ cells $\left(4 \times 10^{6} / \mathrm{ml}\right)$ were added and the incubation was continued for $1 \mathrm{~h}$ at $37^{\circ} \mathrm{C}$. Fifteen- $\mu \mathrm{l}$ aliquots of the virus-cellserum mixtures were plated in duplicate into $200 \mu \mathrm{l}$ of RPMI 1640 media containing $20 \%$ fetal calf serum, $1 \mathrm{mM}$ glutamine, and penicillin/streptomycin in microtiter wells and incubated 4 to 5 days. The cells were then examined by fixed cell indirect immune fluorescence (8) for expression of HTLV-III p24 using a monoclonal antibody (9). In control cultures 50 to $80 \%$ of the cells expressed the HTLV-III core antigen. For test sera, percentages of infected cells were normalized to the control value. Sera for which neutralizing antibody activity could not be detected at the screening dilution of 1:10 were scored negative. Neutralizing antibody titer of positive samples was determined on serially diluted sera and was defined as the reciprocal of the serum dilution at which the percentage of infected cells was $60 \%$ of that in the presence of the control serum. Titers were not corrected for additional dilution factors in the assay system.

Western blot analysis for specific antibodies to HTLV-III antigens was carried out as described previously, detecting antibody binding to HTLV-III antigens on nitrocellulose strips with a mixture of iodinated protein A and goat anti-human IgM (10). Standard antibody titers were determined by testing serially

Table 1. Clinical spectrum of pediatric AIDS and ARC cases

\begin{tabular}{lcc}
\hline & \multicolumn{2}{c}{ Clinical status* } \\
\cline { 2 - 3 } \multicolumn{1}{c}{ Clinical feature } & $\begin{array}{c}\text { Stable } \\
(n=12)\end{array}$ & $\begin{array}{c}\text { Poor } \\
(n=12)\end{array}$ \\
\hline AIDS & 9 & 12 \\
ARC & 3 & 0 \\
Progressive encephalopathy (CNS) & 1 & 10 \\
Candidiasis & 7 & 6 \\
Thymic depletion or atrophy & 1 & 6 \\
P. carinii pneumonia & 0 & 5 \\
Failure to thrive & 4 & 5 \\
Recurrent bacterial infections & 5 & 5 \\
Viral infections (CMV, HSV, EBV) $\dagger$ & 3 & 5 \\
LIP & 7 & 4 \\
Desquamative interstitial pneumonia & 1 & 3 \\
Lymphadenopathy & 4 & 2
\end{tabular}

* The number of children possessing the feature in each group is listed. $\uparrow \mathrm{CMV}$, cytomegalovirus; HSV, herpes simplex virus; EBV, EpsteinBarr virus. diluted samples against a disrupted HTLV-III preparation by the ELISA technique (11). Antibody titer was then expressed as the reciprocal of the serum dilution at which the absorbance of the test serum was equal to the absorbance of a standard negative human serum diluted 1:20.

\section{RESULTS}

Description of pediatric cases. Of the 24 patients represented by the sera investigated, 12 had been classified as clinically well or stable and 12 had been classified as clinically poor. Of the latter group, 10 children had died. The clinical features of each of these groups are compared in Table 1. The predominant and unique features of the clinically poor children included progressive encephalopathy, thymic depletion or atrophy, and Pneumocystis carinii pneumonia. In addition, they shared several clinical manifestations with the stable children. The latter group was characterized mainly by affliction with lymphocytic interstitial pneumonia, candidiasis, and recurrent bacterial infections. Both groups were affected to varying degrees by failure to thrive, lymphadenopathy, and additional viral infections. Another distinctive feature of the two groups of children was their length of survival (Table 2). Except for the two hemophiliacs for whom age at infection was not known, the other children were all infected in utero or in early infancy. All of the stable children were still alive and had survived for more than 2 to $4 \mathrm{yr}$ following onset of disease. In contrast, 10 of the 12 clinically poor children died, and the majority of them had survived for less than $2 \mathrm{yr}$. Although sera were obtained from the clinically stable children at a slightly older age in general compared to the clinically poor children, the age ranges for the groups overlapped. Excluding two hemophiliacs from the clinically poor group whose sera were obtained at more than $10 \mathrm{yr}$ of age, samples from the clinically poor children were obtained from 2 to 74 months of age and from the clinically stable children from 9 to 57 months of age. The mean age of the clinically stable and clinically poor children (excluding the hemophiliacs) was 34.7 and 23.9 months, respectively; $p<0.05$.

Antibody status of pediatric AIDS and ARC cases. Analysis of the sera of the pediatric patients revealed that all $(100 \%)$ of the stable children possessed HTLV-III neutralizing antibodies, while only one of the $12(8 \%)$ clinically poor children had detectable neutralizing antibody activity (Table 3 ). All of the children of both groups were HTLV-III antibody positive by Western blot analysis, and the range of ELISA titers extended upwards of one million for both groups, although the titers of the clinically poor children encompassed more in the lower range compared to the stable children. Although the stable children had a higher geometric mean ELISA titer compared to the clinically poor children, this difference was not statistically significant.

Analysis of the available serial serum samples indicated that the stable children with neutralizing antibodies possessed this reactivity for prolonged periods over the course of their illness (Table 4). Neutralizing antibodies were detected in serial sera from children ranging from 9 to 55 months of age. In contrast, of the three clinically poor children for whom serial serum samples were available, two failed to exhibit neutralizing antibodies at different time periods as widely separated as 12 months.

Table 2. Length of survival postonset of pediatric AIDS and ARC cases

\begin{tabular}{crrcccccc}
\hline & \multirow{7}{*}{$\begin{array}{c}\text { No. of } \\
\text { Pediatric cases }\end{array}$} & \multicolumn{7}{c}{ Yr of survival } \\
\cline { 3 - 9 } & & $<1$ & $>1$ & $>2$ & $>3$ & $>4$ & $>5$ \\
\hline Clinically stable & $0 / 12$ & 0 & 0 & 5 & 3 & 4 & 0 \\
Clinically poor* & $10 / 12$ & 2 & 4 & 1 & 1 & 1 & 1 \\
\hline
\end{tabular}

* Years of survival of two hemophiliacs are not included because age at infection was not known. Both hemophiliacs died; one at age 10 and one at age $11 \frac{1}{2}$. 
Table 3. Neutralizing antibodies in children infected with HTLV-III

\begin{tabular}{|c|c|c|c|c|c|}
\hline \multirow[b]{3}{*}{$\begin{array}{l}\text { Clinical } \\
\text { status }\end{array}$} & \multicolumn{5}{|c|}{ Antibodies to HTLV-III } \\
\hline & \multicolumn{2}{|c|}{ Neutralizing } & \multicolumn{3}{|c|}{ By ELISA } \\
\hline & $\begin{array}{l}\text { No. positive/ } \\
\text { no. tested }\end{array}$ & $\begin{array}{c}\% \\
\text { Positive }\end{array}$ & $\begin{array}{c}\% \\
\text { Positive }\end{array}$ & Range of titer* & $\begin{array}{l}\text { Geometric } \\
\text { mean titer }\end{array}$ \\
\hline Stable & $12 / 12 \dagger$ & 100 & 100 & $1 \times 10^{4}-1 \times 10^{7}$ & $2.8 \times 10^{5}$ \\
\hline Poor & $1 / 12 \ddagger$ & 8 & 100 & $1 \times 10^{2}-1 \times 10^{7}$ & $4 \times 10^{4}$ \\
\hline
\end{tabular}

* The titer of the latest serum sample for each child was used in these calculations.

$\dagger$ All children were antibody positive on all serial serum samples except for one child who was antibody positive but antibody negative on the subsequent sample 2 months later (see Table 4).

$\ddagger$ The one positive child was antibody positive on three of four early serial samples but died 2 yr later. Serum was not available from the time of death (see Table 4).

Table 4. Neutralizing antibody to HTLV-III in serial serum samples of infected children

\begin{tabular}{|c|c|c|c|c|c|}
\hline \multicolumn{3}{|c|}{ Clinically poor children } & \multicolumn{3}{|c|}{ Clinically stable children } \\
\hline Case & $\begin{array}{l}\text { Age } \\
(\mathrm{mo})\end{array}$ & $\begin{array}{c}\text { Neutralizing } \\
\text { antibody titer }\end{array}$ & Case & $\begin{array}{l}\text { Age } \\
(\mathrm{mo})\end{array}$ & $\begin{array}{c}\text { Neutralizing } \\
\text { antibody titer }\end{array}$ \\
\hline \multirow[t]{2}{*}{ A } & 10 & & $\mathrm{D}$ & 23 & 25 \\
\hline & 17 & & & 25 & \\
\hline \multirow[t]{3}{*}{ B } & 10 & & $\mathrm{E}$ & 27 & 70 \\
\hline & 20 & & & 42 & 180 \\
\hline & 22 & & & 48 & 30 \\
\hline \multirow[t]{11}{*}{$\mathrm{C}$} & 19 & 80 & & 53 & 90 \\
\hline & 26 & & & 55 & 25 \\
\hline & 27 & 30 & $\mathrm{~F}$ & 26 & 155 \\
\hline & 31 & 50 & & 28 & 65 \\
\hline & 58 (died) & $\mathrm{NA}^{*}$ & G & 19 & 20 \\
\hline & & & & 30 & 40 \\
\hline & & & & 52 & 35 \\
\hline & & & $\mathrm{H}$ & 9 & 135 \\
\hline & & & & 24 & 110 \\
\hline & & & & 35 & 15 \\
\hline & & & & 37 & 20 \\
\hline
\end{tabular}

* Not available.

The third child possessed neutralizing antibody for 31 months, but subsequently died 2 yr later. Serum samples during this last 2-yr period were not available for analysis.

Analysis of available sera of the IV drug abusing mothers of the pediatric patients showed no relationship between the clinical status of the children and the antibody status of their mothers. Of four mothers of clinically stable children, three possessed neutralizing antibody with titers of 90,120 , and 150. Similarly, three of four mothers of clinically poor children were also neutralizing antibody positive with titers of 20,105 , and 260. Maternal sera from time of birth were not available for analysis.

\section{DISCUSSION}

The serologic studies described here were carried out on coded samples obtained from children previously classified as clinically stable or clinically poor. The finding that $100 \%$ of the stable children possessed detectable HTLV-III neutralizing antibodies in contrast to only $8 \%$ of the clinically poor children was striking. It was tempting to attribute this difference to a progressive decline in the immune system of the clinically poor children with the course of disease. To evaluate this possibility with regard to immunologic response to HTLV-III, we determined standard antibody titers to HTLV-III antigens by the ELISA technique. The ELISA antibody titers to HTLV-III of the clinically poor children were found to range as high as those of the clinically stable children with no statistically significant difference in geometric mean titer between the two groups (Table 3). Five of the clinically poor children, in fact, possessed ELISA titers for HTLV-III antibody greater than 100,000 (data not shown). Thus the clinically poor children lacked HTLV-III neutralizing antibody although their immune response to HTLV-III antigens in general was comparable to that of the clinically stable children. A further indication that the lack of neutralizing antibody in the clinically poor children did not simply reflect a precipitous decline in the immune system prior to death was provided by data on available serial serum samples from two of the clinically poor children who were shown to lack detectable neutralizing antibodies for extended periods of time ( 7 and 12 months, Table 4).

In these studies, age at infection (with the exception of the two hemophiliacs) was not a variable, as all the children were exposed in utero or early infancy. The clinically stable children had survived longer postinfection compared to the clinically poor children, and their serum samples were obtained at a mean age of 34.7 months compared to 23.9 months for the clinically poor children. However, both groups of children were of a mean age to be immunologically competent, and as already pointed out, HTLV-III antibody titers determined by the ELISA technique were not significantly different between two groups. Thus, the slightly older age of the clinically stable children compared to the clinically poor children at time of serologic assay was most likely not a factor in the observed difference in neutralizing antibody status. In support of this view is the finding that serial samples from the stable children at the earliest ages available, including several from children less than 24 months old, possessed neutralizing antibody activity (Table 4). Nevertheless, it will be necessary for long-term prospective studies of children at risk for AIDS to be carried out from birth and thereafter through any subsequent disease which may develop in order to firmly establish both the time course of neutralizing antibody development and the role of maternal antibody and to elucidate any long-term protective role. These studies have been initiated.

The lack of detectable neutralizing antibody among the clinically poor children was not related to a similar lack in their mothers, as the same proportion of mothers from both groups of children possessed neutralizing antibody activity. It will be necessary, however, for future studies to assess maternal neutralizing antibody status at birth, and the extent of passive transfer of maternal neutralizing antibody, in order to determine the role of this immunologic response in virus transmission and/or subsequent disease development in children. Moreover, it will be important to establish whether in utero transmission of HTLVIII is a major mode and whether children of HTLV-III-positive mothers can be infected in early infancy via milk. Whether HTLV-III neutralizing antibodies occur in milk should also be assessed. These questions will be resolved by further study of paired mother and infants at birth and subsequently.

No differences in common variables such as sex or race existed between the two groups of children, and thus the presence or absence of neutralizing antibody activity could not be attributed to these factors. As 23 of the 24 children studied had received intravenous $\gamma$ globulin, this treatment was not a variable contributing to the observed results. We would speculate that other more complex influences, such as immune status at time of HTLV-III infection, and dose of the infecting virus might have some effect on subsequent neutralizing antibody status.

The correlation shown herein between the presence of HTLVIII neutralizing antibody and stable clinical status suggests that neutralizing antibodies in children infected with HTLV-III may confer some degree of protection from disease progression by inhibiting cell to cell spread of the virus. It is worthwhile mentioning, that although the neutralizing antibody titers measured herein may seem low, especially in comparison to the standard ELISA titers, effective protection is not necessarily precluded by such levels. A recent report on the feline leukemia virus, another 
retrovirus which causes both leukemia and immune suppression in infected cats, reports that animals could effectively withstand a viral challenge in the face of measurable neutralizing antibody titers of only 2 to 8 (12). Thus, high neutralizing antibody titer may not be a prerequisite for potential antiviral effect in vivo.

Finally, it is of interest that 10 of the 12 children classified as clinically poor exhibited progressive encephalopathy (Table 1). A reexamination of the data showed that of the 24 children represented in the study, 11 had evidence of CNS involvement, and only two of these 11 exhibited serum neutralizing antibody activity. In contrast, 11 of 13 children with no apparent symptoms of CNS involvement possessed neutralizing antibodies. This correlation of HTLV-III neutralizing antibody with failure to manifest symptoms of progressive encephalopathy was statistically significant $\left(\chi^{2}=5.433\right)$. In this regard, we believe it will be important to pursue studies of HTLV-III neutralizing antibodies not only with regard to a possible protective role and perhaps prognostic utility, but also with an eye to their potential influence on the particular disease spectrum manifested in HTLV-IIIinfected individuals.

Acknowledgments. The authors thank Monica Brown, Andrea Jennings, and Christine Naugle for excellent technical assistance, and Mrs. Dee Goodrich for editorial assistance.

\section{REFERENCES}

1. Wong-Staal F, Gallo RC 1985 Human T-lymphotropic retroviruses. Nature $31: 395-403$
2. Barre-Sinoussi F, Chermann JC, Rey F, Nugeyre MT, Chamaret S, Gruest J, Dauguet C, Axler-Blin C, Vezinet-Brun F, Rouzioux C, Rozenbaum W, Montagnier L 1983 Isolation of a T-lymphotropic retrovirus from a patient at risk for acquired immune deficiency syndrome (AIDS). Science 220:868871

3. Coffin J, Haase A, Levy JA, Montagnier L, Oroszlan S, Teich N, Temin H, Toyoshima K, Varmus H, Vogt P, Weiss R 1986 Human immunodeficiency viruses. Science 232:697

4. Weiss RA, Clapham PR, Cheingsong-Popov R, Dalgleish AG, Carne CA, Weller IVD, Tedder RS 1985 Neutralization of human T-lymphotropic virus type III by sera of AIDS and AIDS-risk patients. Nature 316:69-72

5. Robert-Guroff M, Brown M, Gallo RC 1985 HTLV-III-neutralizing antibodies in patients with AIDS and AIDS-related complex. Nature 316:72-74

6. Centers for Disease Control 1984 Update: acquired immunodeficiency syndrome (AIDS)-United States. MMWR 32:688-691

7. Centers for Disease Control 1985 Revision of the case definition of acquired immunodeficiency syndrome for national reporting-United States. Ann Intern Med 103:402-403

8. Robert-Guroff M, Ruscetti FW, Posner LE, Poiesz BJ, Gallo RC 1981 Detection of the human T-cell lymphoma virus p19 in cells of some patients with cutaneous T-cell lymphoma and leukemia using a monoclonal antibody. $\mathrm{J}$ Exp Med 154:1957-1964

9. DiMarzo Veronese F, Sarngadharan MG, Rahman R, Markham PD, Popovic M, Bodner AJ, Gallo RC 1985 Monoclonal antibodies specific for p24, the major core protein of human T-cell leukemia virus type III. Proc Natl Acad Sci USA 82:5199-5202

10. Clumeck N, Robert-Guroff M, Van de Perre P, Jennings A, Sibomona J, Demol P, Cran S, Gallo RC 1985 Seroepidemiological studies of HTLV-III antibody prevalence among selected groups of heterosexual Africans. JAMA 254:2599-2602

11. Saxinger WC, Gallo RC 1983 Application of the indirect enzyme-linked immunosorbent assay microtest to the detection and surveillance of human T-cell leukemia-lymphoma virus. Lab Invest 49:371-377

12. Osterhaus A, Weijer K, Uytdehaag F, Jarrett O, Sundquist B, Morein B 1985 Induction of protective immune response in cats by vaccination with feline leukemia virus iscom. J Immunol 135:591-596 